\title{
Therapeutics effect of mesenchymal stromal cells in reactive oxygen species-induced damages
}

\author{
Subodh Kumar ${ }^{1} \cdot$ Ranjan Verma $^{1} \cdot$ Nishant Tyagi $^{1} \cdot$ Gurudutta Gangenahalli $^{1} \cdot$ Yogesh Kumar Verma ${ }^{1}$
}

Received: 6 September 2021 / Accepted: 10 November 2021 / Published online: 20 November 2021

(c) The Author(s) under exclusive licence to Japan Human Cell Society 2021

\begin{abstract}
Reactive Oxygen Species are chemically unstable molecules generated during aerobic respiration, especially in the electron transport chain. ROS are involved in various biological functions; any imbalance in their standard level results in severe damage, for instance, oxidative damage, inflammation in a cellular system, and cancer. Oxidative damage activates signaling pathways, which result in cell proliferation, oncogenesis, and metastasis. Since the last few decades, mesenchymal stromal cells have been explored as therapeutic agents against various pathologies, such as cardiovascular diseases, acute and chronic kidney disease, neurodegenerative diseases, macular degeneration, and biliary diseases. Recently, the research community has begun developing several anti-tumor drugs, but these therapeutic drugs are ineffective. In this present review, we would like to emphasize MSCs-based targeted therapy against pathologies induced by ROS as cells possess regenerative potential, immunomodulation, and migratory capacity. We have also focused on how MSCs can be used as next-generation drugs with no side effects.
\end{abstract}

Keywords Reactive oxygen species $\cdot$ Electron transport chain $\cdot$ Oxidative stress $\cdot$ Cancer $\cdot$ Metastasis $\cdot$ Mesenchymal stromal cells

$\begin{array}{ll}\text { Abbreviations } \\ \text { ROS } & \text { Reactive oxygen species } \\ \text { MSCs } & \text { Mesenchymal stromal cells } \\ \text { EMT } & \text { Epithelial-Mesenchymal transition } \\ \text { ATM } & \text { Ataxia-telangiectasia mutated } \\ \text { JNK } & \text { C-Jun N-terminal kinases } \\ \text { HGF } & \text { Hepatocyte growth factor } \\ \text { ERK } & \text { Extracellular regulated kinases } \\ \text { MD } & \text { Mascular degeneration } \\ \text { NDs } & \text { Neurodegenerative diseases } \\ \text { CKD } & \text { Chronic kidney disease } \\ \text { ETC } & \text { Electron transport chain } \\ \text { FoxO } & \text { Forkhead box protein O } \\ \text { SOD3 } & \text { Superoxide dismutase 3 } \\ \text { PGE2 } & \text { Prostaglandin E Synthase 2 } \\ \text { SOD1 } & \text { Superoxide dismutase 1 } \\ \text { TGF- } \beta & \text { Transforming Growth Factor Beta } 1\end{array}$

Yogesh Kumar Verma yog.kverma@gmail.com

1 Stem Cell \& Gene Therapy Research Group, Institute of Nuclear Medicine \& Allied Sciences (INMAS), Defence Research and Development Organisation (DRDO), Lucknow Road, Timarpur, Delhi 110054, India
MAPKs Mitogen-activated protein kinase

CNS Central nervous system

hUMSCs Human umbilical cord mesenchymal stromal cells

HSV-TK Herpes simplex virus-thymidine kinase

CCL5 C-C motif chemokine Ligand-5

SLE Systemic lupus erythematosus

GVHD Graft versus host disease

IL1RN Interleukin-1 receptor antagonist

TNF- $\gamma \quad$ Tumor necrosis factor- $\gamma$

\section{Introduction}

Various cells and organelles, for instance, mitochondria peroxisomes, phagocytic cells, and endoplasmic reticulum produce reactive oxygen species (ROS) during their biological functioning [1-3]. Phagocytic cells, peroxisome, and endoplasmic reticulum contribute less towards ROS production as compared to mitochondria ( $80 \%$ of free radicals are generated in mitochondria) [4]. ROS are generated as a combination of free electrons with a by-product of oxygen molecules [5]. The intracellular presence of two free electrons in the outer orbital of oxygen molecule 
makes cells more susceptible to form free radicals [6]. The addition of free electrons to these oxygen molecules leads to the formation of several other ROS species, such as superoxide, hydrogen peroxide, hydroxyl radical, hydroxyl ion, and nitric oxide [7-10]. These free reactive species influence various functions, such as gene expression, cell cycle activation, proliferation, angiogenesis, and apoptosis [11-13]. Furthermore, ROS are known to play a role in intra- and inter-cellular signaling for a variety of cellular processes [14]. Oxidative balance is one of the critical factors responsible for normal cellular growth and maintenance [15]. In the past few decades, disruption of redox balance has been illustrated as an important reason underlying cancer progression, angiogenesis, and metastasis in human cells [16-18]. ROS are also responsible for acute and chronic kidney disease (CKD), neurodegenerative diseases (NDs), macular degeneration (MD), and biliary diseases [19-22]. The disproportionality in redox homeostasis is associated with increased free radicals, predominantly ROS [23]. The ROS and highly active radicals act intrinsically and extrinsically in the cell microenvironment and cause severe consequences; cancer is one among them [24]. Because of mesenchymal stromal cells (MSCs) therapeutic and regenerative potential, as well as the recent development of MSCs as targeted-based therapeutics, scientists are increasingly turning to MSCs as a better alternative to cure ROS-induced damage. Among all the stem cells, MSCs have very high disease-based targeted potential due to their multilineage differentiation potential, migratory capacity to injured sites, and response to environmental signals through paracrine mediators [24, 25]. Nevertheless, several new emerging data support the beneficial effects of MSCs for oncological pathogenesis [26].

\section{ROS-induced inflammation}

Inflammation is a natural defence mechanism against pathogens [27], but ROS-induced inflammation is associated with chronic diseases, such as kidney failure, neurodegeneration, and many types of cancer [28, 29]. Generally, cells contain a limited amount of ROS in their microenvironment as it is necessary for their cellular function, but if there is an imbalance in their concentration, it leads to perturbations [30]. ROS exerts a negative effect on nucleic acid (DNA/RNA), protein, and fatty acids [31, 32]. ROS causes unfavorable changes in these molecules, resulting in the release of inflammatory signaling molecules and the progression of cancers and chronic diseases[33]. These inflammatory molecules disrupt normal cellular functions by activating signaling pathways mediated by NF- $\mathrm{BB}$, JAK-STAT3, MAPK, PI3K/Akt/mTOR, Wnt/ $\beta$-catenin, and TGF- $\beta /$ Smad [34-37]. There are few ROS, like superoxide, which combine with NO to form another highly unstable peroxynitrite molecule[38] and have proinflammatory effects [39]. Some ROS directly influence cell death by activating apoptotic signaling (Fig. 1), implying a role in cell aging.
Fig. 1 Mitochondrial-induced inflammation and apoptosis

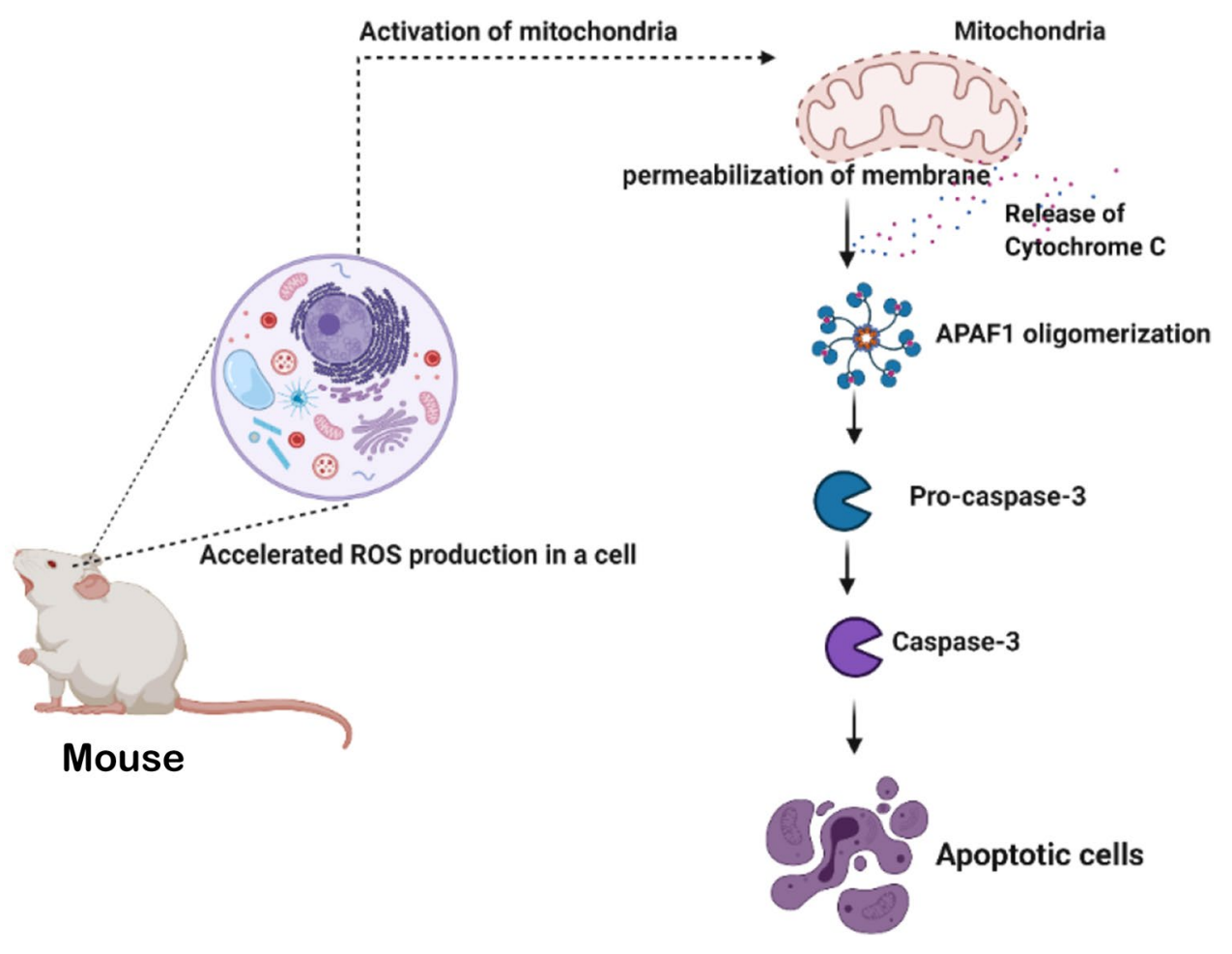




\section{Mechanism of inflammation}

\section{Uncoupled NOS-derived ROS in inflammation}

Nitric oxide synthase (NOS) mediates synthesis of nitric oxide (NO) from L-arginine. NOS belongs to the large family of enzymes known as nitric oxide synthases (NOSs) [40]. In a cell, there are three isoforms of NOS, namely, neuronal (nNO), inducible (iNO), and endothelial (eNO), having significant functions [41]. Among these, eNOS is a predominant source of NO in the vascular endothelial cells [42]. It is a dimer protein with a reductase domain at its $\mathrm{N}$-terminal, responsible for binding three cofactors, namely NADPH, FMN, and FAD. Its oxygenase domain binds to prosthetic heme group, cofactor tetrahydrobiopterin $\left(\mathrm{BH}_{4}\right)$, and molecular oxygen. During synthesis of NO, free electrons are generated, which are transferred from tightly bound NADPH (reductase domain) to the heme prosthetic group of oxygenase domain [43]. The synthesis of NO by eNOS is a controlled process. eNO tightly regulates electron transfer, however, any change may result in the production of superoxide radicals, which have been linked to a variety of inflammatory diseases, including acute lung injury, diabetes mellitus, and others [44].

\section{Mitochondrial role in inflammation}

As discussed earlier, $80 \%$ of ROS are generated in mitochondria, known as mtROS. These ROS are prominently involved in inflammation [45]. An increased level of mtROS has been reported in patients' blood samples (having monocytes and neutrophils) compared to the normal healthy individual. A low level of ROS activates mitochondrial-targeted ubiquitin (MitoQ), suppresses p38MAPK activation, and leads to production of pro-inflammatory cytokines, such as IL-6 and TNF- $\alpha[46,47]$. Some new studies suggest that tumour necrosis factor receptor 1 (TNFR1) associated mutation elevates mROS level, although the mechanism is not very clear [48]. However, one of the possible mechanisms may be retention of the mutated protein in endoplasmic reticulum (ER), which releases calcium and further alters the ETC of mitochondria. Any discrepancy in ROS level and rate of ROS synthesis is sensed by two complex proteins viz. Trx and thioredoxin interacting protein (TXNIP). When these proteins dissociate, TXNIP binds to NLRP3 for its activation, which enables recruitment of apoptosis-associated speck-like protein (Asc) and Pro-caspase1/2protein (precursor of NLRP3 inflammasome formation). The active form of NLRP3 inflammasome changes pro-IL- $1 \beta$ and pro-IL-18 into an active form by cleaving nascent peptide that is subsequently secreted by the inflammatory cells. These nascent peptides subsequently promote angiogenesis, tumour cell migration, and tissue invasion $[49,50]$.

\section{ROS-induced pathologies}

The ROS as inflammatory mediators trigger various health complications, as they influence many signaling cascades which hamper the function of nucleic acids, proteins, and fatty acids. This results in the onset of various abnormalities, as discussed further.

\section{Neurodegeneration}

Neurons play a pivotal role in regulating sensory organ functions. Any defect in neurons' function and associated signaling causes neurological disorders (Alzheimer's, dementia, Parkinson's, etc.) [39]. These cells are more sensitive to oxidative damage due to the unavailability of antioxidant molecules [30]. As a result, any mitochondrial dysfunction elevates ROS levels, which subsequently activates c-Jun N-terminal kinase (JNK), and sterol regulatory element-binding proteins (SREBP), causing accumulation of lipid droplets and consequent neurodegeneration [10].

\section{Cardiac diseases}

An imbalance of ROS level in cardiac cells stimulates TNF- $\alpha$, Angiotensin II, and norepinephrine. ROS are considered prime molecules responsible for cardiac diseases, such as myocardial infarction and heart failure [51]. Myocardial ischemia (heart muscles with insufficient blood supply) is the most prominent cause of heart attack. A high level of ROS is associated with ischemia-reperfusion injury, resulting in the apoptosis of cardiomyocytes [52]. During ischemia, the heart suffers from a lack of ATP supply, which causes calcium accumulation and, as a result, an increase in ROS levels destabilizes the integrity of the plasma membrane and ultimately leads to cell death [39].

\section{Inflammatory diseases and infection}

Under standard conditions, ROS regulate immune response and bring about oxidative damage [53]. They stimulate Nod-like receptor (NLR) family and pyrin domain-containing 3 (NLRP3) caspase 1, IL-1 $\beta$, and IL-18 [54]. The sensitivity of T-cells for ROS affects their development and function. For instance, TH17 cells participate in several inflammatory and autoimmunity diseases such as Encephalomyelitis (EAE) [55]. Controlled regulation of ROS level aborts EAE development. Any imbalance in ROS level engenders cytotoxicity and damage to DNA, protein, and lipids. These damages further trigger 
apoptosis, inflammatory bowel disease, and autophagy [56].

\section{Organ failure}

Prolonged oxidative stress can severely affect the functioning of organs and, in extreme conditions, kindle organ failure. ROS activate signaling through tumor necrosis factor (TNF- $\alpha$ ), responsible for liver failure. The activation of TNF- $\alpha$ downstream molecules, JNK, and cytochrome-c results in necrotic cell death. In parallel, Ferritin heavy chain (FHC) induces downstream NF- $\kappa b$. This subsequently suppresses accumulation of ROS by iron sequestration, thereby inhibiting JNK signaling [57].

\section{Cancer development}

In the development of cancer, ROS has a detrimental role. Oxidative stress, caused by an imbalance between ROS production and antioxidative defense mechanisms, promotes mutation in DNA, RNA, protein, and cell signaling activation. Moreover, an elevated level of ROS has been observed in most cancers as they manipulate the cancer microenvironment, upregulate metabolic activity, cell cycle progression (accelerate proliferation), interrupt cell cycle regulation, apoptosis, and angiogenesis [58]. An oxidizing agent and disinfectant, hydrogen peroxide $\left(\mathrm{H}_{2} \mathrm{O}_{2}\right)$, causes hydroxylation of DNA via the Fenton reaction (in this reaction, metals like $\mathrm{Fe}, \mathrm{Cu}$ use $\mathrm{H}_{2} \mathrm{O}_{2}$ as a catalyst for accepting or donating electrons). The hydroxyl radicals thus produced damage DNA by generating lesions, single- and double-stranded breaks, and suppressing DNA repair machinery.

As a consequence, these changes provoke mutation and cancerous growth. ROS also affect the protein functioning through oxidative modification, thus resulting in altering amino acids' sequence and elevating the chances of protein carbonylation, nitration of tyrosine and phenylalanine residues, and protein degradation. The oxidation of amino acids and enzymes can influence the function of proteins; for instance, the enzymatic activity of DNA repair enzyme, the fidelity of DNA polymerase, replication/ transcription activity induce the onset of cancer. Besides DNA, ROS also affects lipids as they beget peroxidation when interacting with poly-saturated and poly-unsaturated fatty acids. Some studies suggest that lipid peroxidation is also responsible for tumorigenesis. For instance, presence of thiobarbituric acid in the serum of colorectal cancer patients indicates a high level of lipid peroxidation.

\section{Cancer progression}

Several types of cancer are triggered by ROS, such as hydrogen peroxide, superoxide, etc., which enhance cell proliferation. Manganese Superoxide Dismutase (MnSOD) enzyme acts as mitochondrial ROS switch and regulates cell proliferation and quiescence. The decreased level of MnSOD stimulates cell proliferation, while on the other hand, its elevated level promotes quiescence [59]. In case of breast cancer, translocation of estrogen to the mitochondria has been reported to induce oxidative stress affecting Erk1/2 MAP signalling and activation of cyclic AMP response element-binding protein (CREB). This results in excessive cell proliferation. Some studies have suggested a pivotal role of ROS in tumor cell-cycle regulation, as ROS control the expression of cyclins, such as cyclin B2, D3, E1, and E2. In addition, ROS upregulates the mRNA level of these cyclins during G1- to S-phase transition. Some carcinogenic substances, such as sodium arsenite and benzopyrene quinines, stimulate ROS synthesis and adversely affect growth factor signaling to induce cell proliferation. Ataxia-telangiectasia mutated (ATM) protein, involved in cell cycle regulation, is also influenced by ROS. The absence of ATM heralds cancer proliferation.

\section{Cancer metastasis and angiogenesis}

After tumor establishment, cells start migration from the primary site and invade distant secondary organs through metastasis [60, 61]. It is a multistep, complex process involving many transcription factors, such as NF-kB, ETS protooncogene 1 transcription factor (ETS-1), AP-1, Twist, zinc finger E-box-binding homeobox (Zeb); metalloproteins, such as MMP-2, MMP-9; and chemokines such as TGF- $\beta$. The leading cause of metastasis is the epithelial-mesenchymal transition (EMT), where epithelial cells lose contact inhibition and acquire mobility and penetrance. Several studies have suggested that ROS play a role in EMT [62]. Activation of cell migration and invasion is regulated by the Urokinase-type plasminogen activator and MMP-9, which are activated by TGF-1 and NADPH oxidase 4 (NOX-4) [63]. All these factors are shown to be triggered by ROS. Mitochondrial $\mathrm{Ca}^{2+}$ also plays a pivotal role in the onset of metastasis; the expression of mitochondrial calcium uniport regulator 1 (MCUR1) is increased during hepatocellular carcinoma, resulting in EMT of tumour cells by ROS/Notch/ Nrf 2 signalling pathway. Due to critical involvement of MCUR1 in hepatocellular carcinoma, it is a prime target during treatment of such cancer. According to Aydin and his colleagues, NOX-2 influences ROS-mediated metastasis by downregulating NK cells, and NOX-2 inhibition can restore IFN dependent clearance of myeloma cells by NK cells. Vimentin is a type III intermediate filament protein 
that is expressed in mesenchymal cells [64]. Oxidative stress caused by HIF-I regulates unnecessary gene transcription during cancer cell progression, EMT, and metastasis. Inhibition of vimentin by RNAi is used in the treatment of various cancers.

Angiogenesis is a process of establishment of new blood vessels. These new blood vessels accelerate the progression and spread of cancer as they supply oxygen and cellular nutrients required by cancerous cells [65]. Vascular epithelial growth factor (VEGF) and hypoxia elevate intracellular ROS in the cellular niche, resulting in new blood vessels development. HIF-1 initiates VEGF expression during hypoxia, but suppressing endogenous ROS levels reduces HIF-1 and VEGF expression (Hypoxia-Induced Angiogenesis). ROS stimulates MMP1 secretion from tumor cells, which promotes blood vessel spread in the tumor cell's center. Moreover, transitions of MMP-1, MMP-2, and MMP-9 are associated with elevation of the endogenous level of ROS, which promotes capillaries formation, vasodilation, and increased blood supply through activation of heme oxygenase-1 (induces nitric oxide synthesis) in tumour cells [66].

\section{Anti-ROS therapeutics}

Various ROS inhibitors, such as ascorbic acid, $\alpha$-tocopherol, and $\beta$-carotene, have been studied for their beneficial effects in mitigating ROS-induced damage. The mechanisms of ROS suppression are different from each other; for example, vitamin $\mathrm{C}$ aids in reversing endothelial dysfunction in patients with coronary artery disease [67]. While $\alpha$-tocopherol positively reacts with lipid radicals to protect the cell membrane, whereas $\beta$-carotene prevents oxidative cellular damage by converting itself into bioactive retinol form.

\section{Mesenchymal stromal cells (MSCs)}

MSCs are non-hematopoietic, multipotent and a heterogeneous group of stromal stem cells isolated from various sources, including bone marrow, adipose tissue, umbilical cord matrix, tendon, lung, and periosteum [68, 69]. These cells can potentially differentiate into mesodermal lineages, such as adipocytes, chondrocytes, osteocytes, ectodermal and endodermal lineages [70].

There are three golden standards for MSCs characterization as defined by the International Society of cellular therapy [71]. First, MSCs are adherent cells having a plastic-adherent nature. These cells attach to a culture plate in standard culture conditions. Second, a flow cytometry study revealed that more than $95 \%$ MSCs population express CD105, CD73, and CD90 cell surface antigens, and they were originally recognized by the $\mathrm{mAb} \mathrm{SH} 2, \mathrm{mAb} \mathrm{SH} 3$, and SH4 and Thy-1, respectively. Furthermore, MSCs lack the expression of CD45 (leukocyte marker), CD34 (hematopoietic progenitors and endothelial cells), CD14 (monocytes marker), or CD11b (macrophages marker), CD79a or CD19 (B cells antigen), and HLA class II antigen. Third and last criteria, one special property that is uniquely present in MSCs, the ability to differentiate into osteoblasts (Fig. 2) (identified using Alizarin Red or von Kossa staining), adipocytes (identified using Oil Red O), and chondroblasts
Fig. 2 Differentiation of MSCs into lineages, such as myocyte, chondrocyte, adipocyte, osteoblast, and neurons

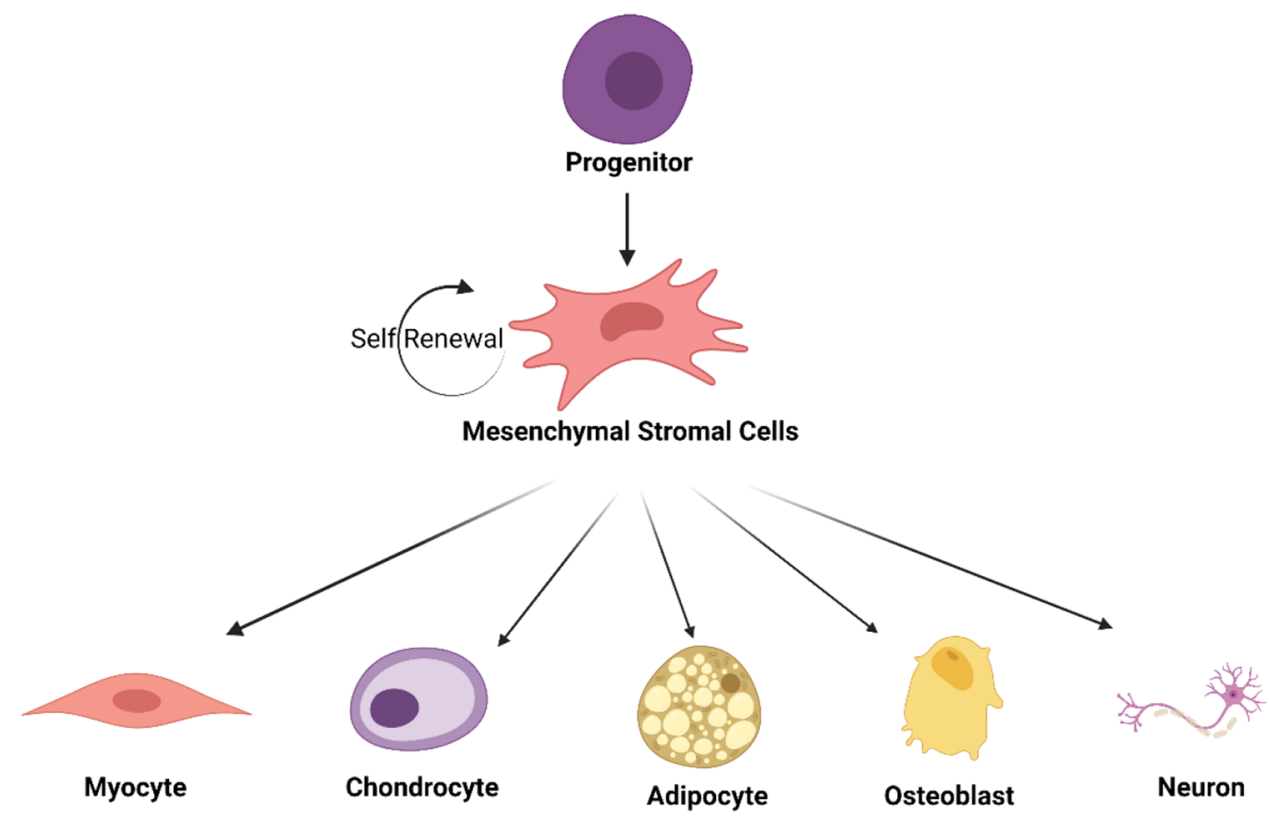


(identified using staining with Alcian blue) under the standard condition in vitro.

The differentiation of progenitor MSCs into a specific lineage is mediated by both intrinsic and extrinsic factors present in their niche. These factors also control molecular and cellular patterns of MSCs-derived lineages. MSCs readily interact with the immune system (both innate and adaptive immune systems) and mediate the functioning of immune response; for instance, NK cell cytotoxicity, antigen presentation by dendritic cells (DCs), and activation of neutrophils are regulated by MSCs. These cells also promote peripheral tolerance by migration to an inflammatory site and release pro-inflammatory cytokines, resulting in enhanced survival of damaged cells [72].

\section{Multipotentiality of MSCs}

(a) Differentiation and regenerative potential

MSCs possess self-renewal and differentiation capabilities [73]. Some studies have suggested that MSCs can also differentiate into ectodermal and endodermal lineages, including hepatocytes and neurons. This is beyond their conventional mesodermal speciation due to limited power of differentiation. There is little information available on MSCs differentiation in vivo owing to lack of specific MSCs markers. MSCs engraftment and trans-differentiation in vivo into bone, cartilage, myocardium, neuron, and hepatic tissues cannot be identified, this requires a better understanding of MSCs markers [73, 74].

(b) Immune modulation

MSCs are known to display potent immunosuppressive and anti-inflammatory effects when they interact with lymphocytes. These cells negatively regulate $\mathrm{T}$ cell, B cell, NK cell proliferation, cytokines production, and maturation of dendritic cells [75]. Importantly, MSCs can overcome all the complications associated with allogeneic rejection in human and animal models due to hypo-immunogenic properties as they do not express major histocompatibility complex type II (MHC-II) and other costimulatory molecules [76-78].

\section{(c) Migratory capacity}

The migratory potential of MSCs plays a significant role in reducing the ROS-induced inflammation as these cells migrate to the inflammatory site with the help of chemokines and cell surface receptors \{stromal cell-derived factor 1 (SDF-1), C-X-C chemokine receptor type 4 (CXCR4), stem cell factor, hepatocyte growth factors (HGF), vascular endothelial growth factor (VEGF)/VEGF receptor, platelet-derived growth factor (PDGF), monocyte chemoattractant protein-1 (MCP-1), and $\mathrm{C}-\mathrm{C}$ chemokine receptor type 2 \} [79].

The tumor microenvironment constantly produces many cytokines, chemokines, and other adhesion molecules as inflammatory mediators, which serve as chemoattractants for MSCs at the site of inflammation [80]. For example, the chemokine receptor pair, SDF-1, and CXCR4 act as an important mediator of stem cell recruitment, especially MSCs at the tumor sites [81]. The tumor microenvironment arouses hypoxic conditions and upregulates hypoxia-induced transcription factor, HIF- $1 \alpha$. This protein activates proangiogenic molecules, such as vascular endothelial growth factors (VEGF), fibroblast growth factors (FGF-2), macrophage migratory inhibitor factors, tumour necrosis factors, and numerous proinflammatory cytokines. Simultaneously inducing MCP-1 chemokine, involved in migration of MSCs toward tumor [25].

In the tumor niche, MSCs interact directly or indirectly with tumor cells and affect tumor development. In indirect mode, MSCs secrete various inhibitory growth factors and cytokines as paracrine factors, which act on inflammatory cells (cancer) and disrupt cellular proliferation, cell survival, angiogenesis, etc. In direct mode, MSCs interact with tumor cells and exert their therapeutic effects through inhibiting proliferation-related signaling pathways, such as PI3K/AKT, cell cycle, etc. [82, 83] (Fig. 3).

\section{Thepauetics mechanism of MSCs and HSCs}

Most stem cells prefer anaerobic glycolysis over oxidative phosphorylation to maintain a low ROS level in the cell [84]. During oxidative phosphorylation, the rate of ROS generation is increased due to continuous electron transport through various metabolic cycles. MSCs are ideal contender for cell-based therapy for tissue injury [85]. They regulate various kinases, such as mitogen-activated protein kinases (MAPKs), c-Jun N-terminal kinases (JNKs), p38, and extracellular signal-regulated kinases (ERKs), that positively accelerate ROS synthesis. In the elevated ROS environment, MSCs differentiate themselves into three lineages, namely adipocyte, osteocyte, and chondrocyte. Under pathological conditions, production of ROS is increased [39]. The regulatory mechanism of ROS in stem cells is governed by ATM (the gene responsible for ataxia-telangiectasia). After serial transplantation, an increased level of ROS in ATM mutation was observed due to deregulation of major antioxidative systems and activation of p38 MAPK, resulting in depletion of normal HSCs.

Furthermore, this decreased reconstitution capacity was normalized by treatment with an antioxidant. These studies suggest ROS's role in the impaired function of ATMdeficient HSCs. Some evidence has also suggested the 


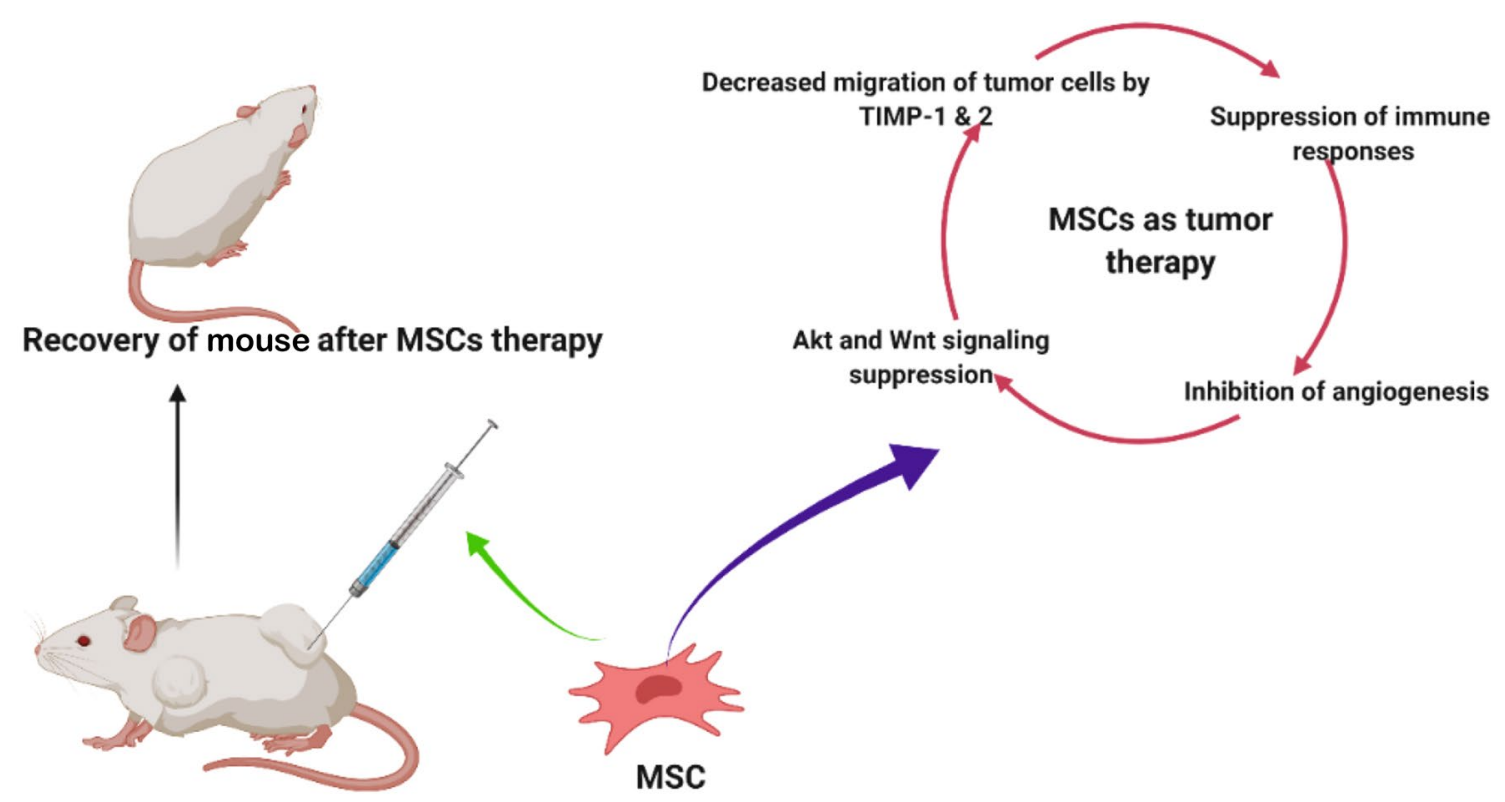

Tumor induced mouse

Fig. 3 Anti-tumorogenic effect of MSCs

involvement of ROS in the regulation of forkhead homeobox type $\mathrm{O}$ (FoxO) transcription factors, promotion of glycolysis, and autophagy [86]. These molecules serve as key regulators of tumour suppression through cell-cycle arrest and metabolism regulation of tumour cells. Currently, available therapeutics applications of MSCs in several diseases are listed in (Table 1).

\section{Role of MSCs-derived secretome}

ROS stimulate a cascade of processes, including inflammation, angiogenesis, programmed cell death (Fig. 4), autophagy, and crosstalk of activated signal transduction pathways [87]. These processes participate in generating proinflammatory cytokines, such as interleukin- $1 \alpha$ (IL-1 $\alpha)$, IL-1 $\beta$, IL-6, and profibrogenic cytokines, such

Table 1 Application of MSCs in various complications

\begin{tabular}{|c|c|c|}
\hline S. no. & Diseases & Role of MSCs therapy \\
\hline 1 & Bone and cartilage diseases & $\begin{array}{l}\text { Osteogenesis imperfections and other bone disorders have reported a positive effect of MSCs-based therapy } \\
\text { [94] }\end{array}$ \\
\hline 2 & BMT and GVHD & $\begin{array}{l}\text { Graft versus host disease (GVHD) treatment have yielded promising result, but the therapeutic efficacy of } \\
\text { MSCs is less clear [94] }\end{array}$ \\
\hline 3 & Cardiovascular diseases & MSCs-based therapy has shown a positive role in improving cardiac repair [95] \\
\hline 4 & Autoimmune diseases & $\begin{array}{l}\text { The systemic lupus erythematosus (SLE) is an autoimmune inflammatory disease where the positive role } \\
\text { of MSCs therapy has been reported. SLE involves multiorgans, such as kidney, brain, lung, and hemat- } \\
\text { opoietic systems [96] }\end{array}$ \\
\hline 5 & Liver diseases & $\begin{array}{l}\text { The immunomodulatory properties of MSCs have been used in the treatment of liver diseases } \\
\text { In a phase I trial, four patients suffering from end-stage liver cirrhosis were treated with autologous MSCs } \\
\text { resulted in the improvement of liver function } \\
\text { I to II clinical trial in eight patients with last-stage liver diseases received autologous MSCs. It improved } \\
\text { liver functions [97] }\end{array}$ \\
\hline 6 & Cancer & $\begin{array}{l}\text { MSCs inhibit tumor growth and angiogenesis as they may contain regulatory mechanism responsible for } \\
\text { growth and angiogenesis of tumour cells } \\
\text { Various preclinical gene-modified MSCs have been used to treat cancer }[98,99]\end{array}$ \\
\hline 7 & COVID19 & $\begin{array}{l}\text { MSCs can increase the lymphocyte count and regulatory DCs to raise their antiviral characteristic, resulting } \\
\text { in the decreased level of C-reactive protein and pro-inflammatory cytokines (IL-6, TNF } \alpha \text {, IL- } 8 \text {, and so } \\
\text { on), which are the main markers of inflammation [100] }\end{array}$ \\
\hline
\end{tabular}




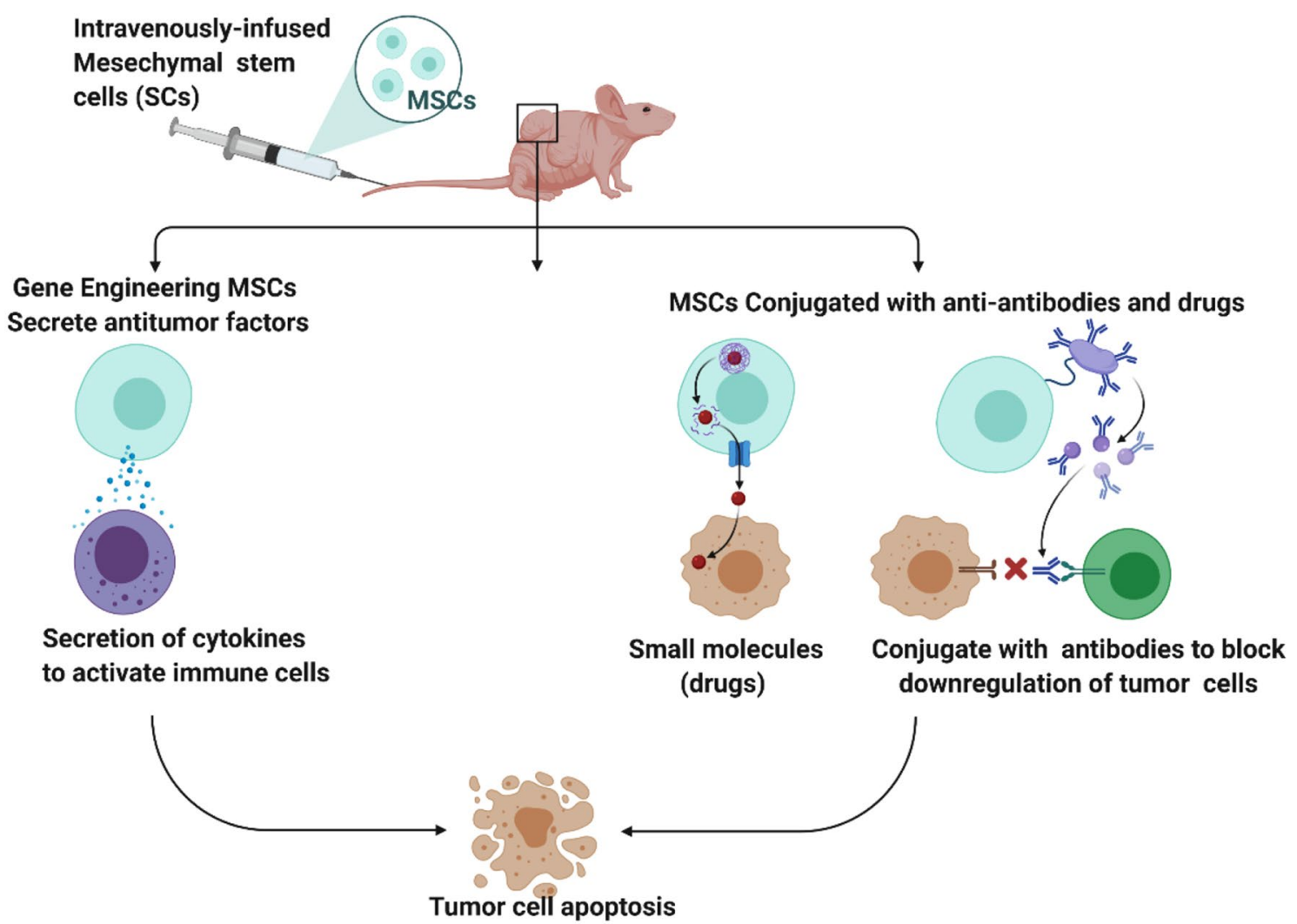

Fig. 4 Anti-viral therapy of mesenchymal stromal cells (MSCs)

as transforming growth factor $\beta 1$ (TGF- $\beta 1$ ), etc. [88, 89]. MSCs secrete paracrine cytokines, superoxide dismutases, or soluble inflammatory cytokine receptors, which activate anti-inflammatory and anti-fibrotic signalling or neutralizing proinflammatory and profibrotic cytokines [90]. All these activities may assist in reducing ROS-induced damage. The sT $\beta \mathrm{R}$ protein down-regulates expression of TNF- $\alpha$, IFN- $\gamma$, IL-6, and TGF- $\beta$ (Fig. 5). While the MSCs-derived HGF inhibits TNF- $\alpha$, IFN- $\gamma$, IL- 6 , TGF- $\beta$, and myofibroblasts in ROS-damaged cells [91]. Another factor, PGE2, increases anti-inflammatory IL-10. Whereas SOD helps in scavenging ROS and subsequently decreases the amount of ROS-induced damage [92]. A family member of SOD family, SOD3, also reduces inflammatory cell infiltration and oxidative stress in cells. IL1RN, like others, also suppresses the inflammation by inhibiting the IL- $1 \alpha$, IL-1 $\beta$, and TNF- $\alpha$ and thus prevents cellular damage (Fig. 5) [93].

\section{Clinical trials of MSCs for therapeutics}

A large number of clinical trials were performed emphasizing the therapeutic role of MSCs in various pathologies, for example, heart disease, liver failure, neurodegeneration, and cancers [79, 101-103]. Many MSCs-based clinical trials are also registered to find their role in the treatment of solid tumors. For the first time, engineered MSCs-based treatment was performed against gastrointestinal tumors. In this study (phase I/II stage), researchers used MSCs for the delivery of herpes simplex virus-thymidine kinase (HSV-TK) under the control of the $\mathrm{C}-\mathrm{C}$ motif chemokine Ligand-5 (CCL5) promoter. Recently, a clinical trial was registered to evaluate the safety and highest tolerable dose of human MSCs expressing interferon- $\beta$ that can be administered to patients undergoing treatment for the last stage of ovarian cancer. Like MSCs, secreted exosomes derived from MSCs also have a potent therapeutic potential against targeted tumour therapy (Fig. 6) [104, 105]. Meanwhile, to accelerate and transform preclinical research to clinical application, the research fraternity needs to emphasize the efficacy and safety of these therapeutic approaches provided by preclinical studies $[74,106]$. The current clinical trials of MSCs are listed in Table 2.

\section{MSCs as a novel cell-based drug}

The application of medication can have adverse effects, whether a prescription drug or an alternative that includes herbals or vitamin supplementation provided through external sources. The novel idea is that the application of cellbased therapy against diseases like cancer, Alzheimer's, 
Fig. 5 Role of MSCs-derived secretome in ROS-induced damages

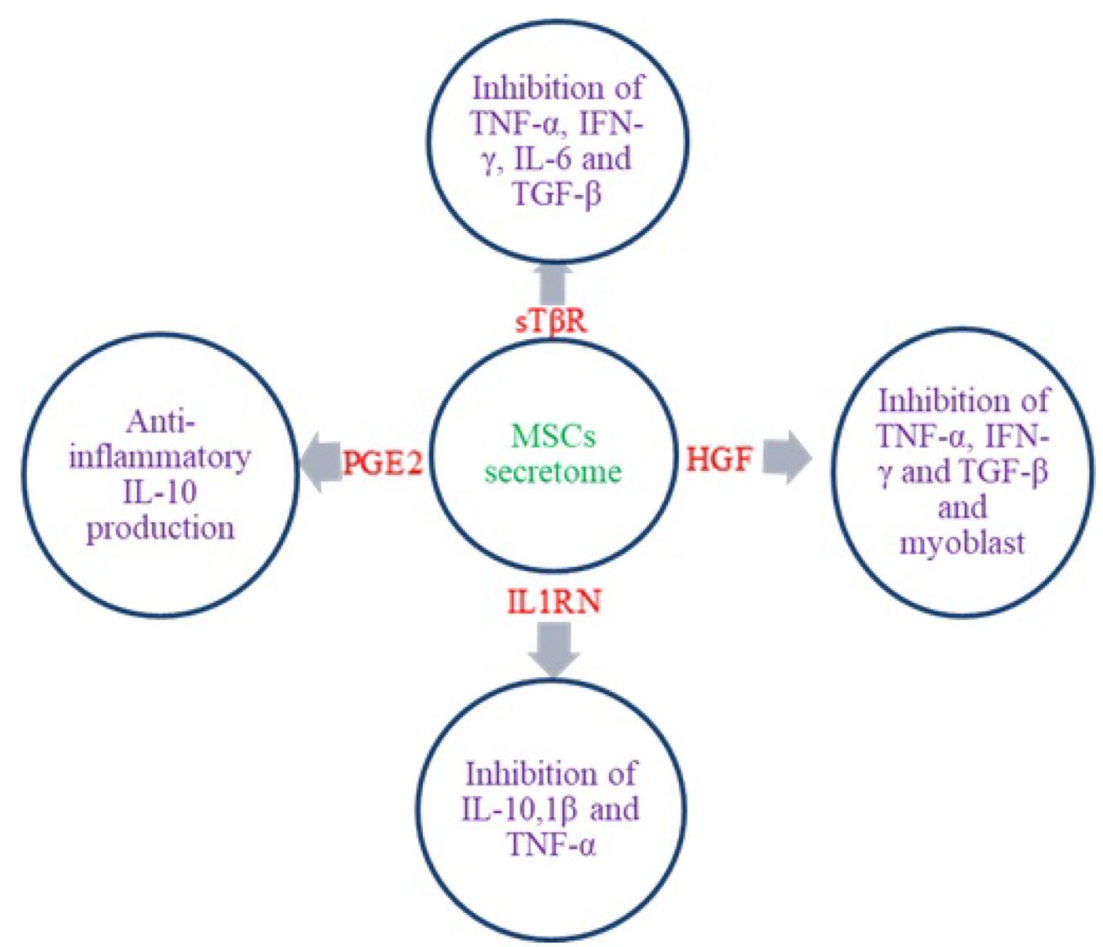

Inhibition of

L-6 and

TNF- $\alpha$, IFN-

$\gamma$ and TGF- $\beta$

and

myoblast
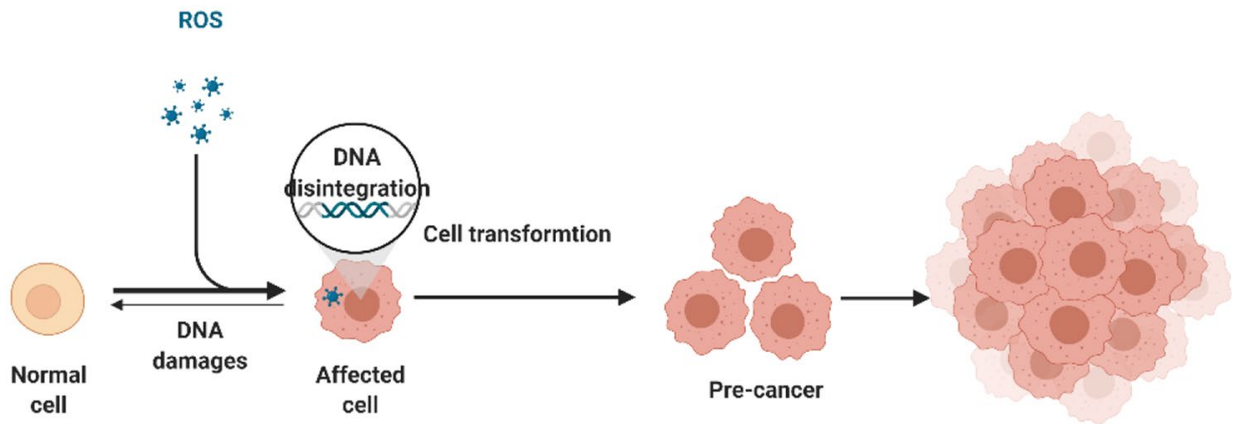

Cancer

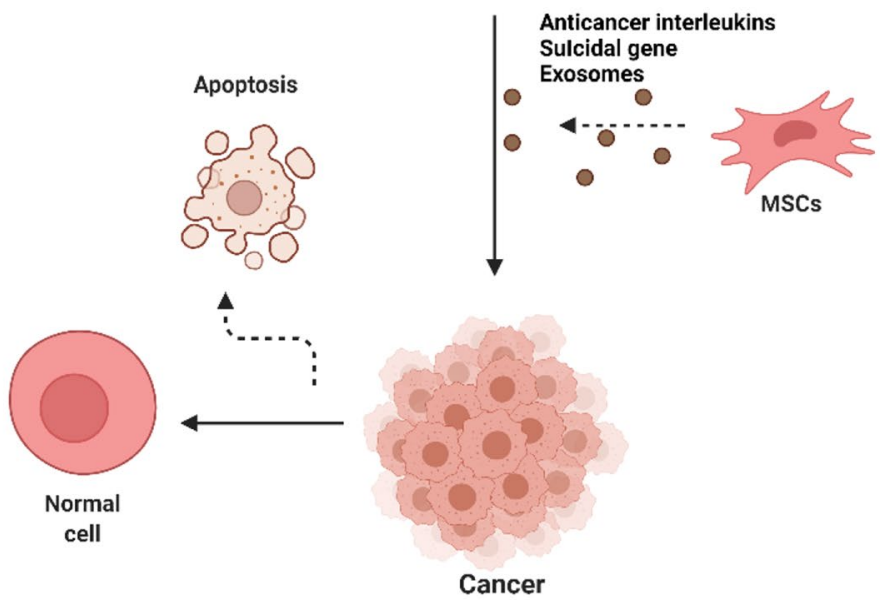

Fig. 6 Clinical application of genetically modified MSCs as anti-tumorigenic 
Table 2 List of clinical trials on stem cells/MSCs in various pathologies caused by ROS [107]

\begin{tabular}{|c|c|c|c|c|c|}
\hline Clinical trial number & Title & Study phase & Status & Responsible party & Country \\
\hline NCT03106662 & $\begin{array}{l}\text { MSCs infusion in a hap- } \\
\text { loidentical patient with } \\
\text { haematological malignan- } \\
\text { cies }\end{array}$ & Phase 3 & Completed & $\begin{array}{l}\text { OnderArslan, Ankara } \\
\text { University }\end{array}$ & Turkey \\
\hline NCT02530047 & MSCs for ovarian cancer & Phase 1 & Completed & $\begin{array}{l}\text { University of Texas, MD } \\
\text { Anderson Cancer Center }\end{array}$ & Texas, United States \\
\hline NCT03096782 & $\begin{array}{l}\text { Umbilical cord blood } \\
\text { transplant with added } \\
\text { sugar and chemotherapy } \\
\text { and radiation therapy } \\
\text { in treating patients with } \\
\text { leukaemia or lymphoma }\end{array}$ & Phase 2 & Recruiting & $\begin{array}{l}\text { M.D. Anderson Cancer } \\
\text { Center }\end{array}$ & Texas, United States \\
\hline NCT04074408 & $\begin{array}{l}\text { Intracavitary injection of } \\
\text { hUMSCs in acute basal } \\
\text { ganglia hematoma after } \\
\text { stereotactic aspiration }\end{array}$ & Phase 2 & Recruiting & $\begin{array}{l}\text { Second affiliated hospital, } \\
\text { School of Medicine }\end{array}$ & Zhejiang, China \\
\hline NCT02068794 & $\begin{array}{l}\text { MV-NIS infected MSCs } \\
\text { in treating patients with } \\
\text { recurrent ovarian cancer }\end{array}$ & Phase 1/ Phase 2 & Recruiting & Mayo Clinic & $\begin{array}{l}\text { Rochester, Min- } \\
\text { nesota, United } \\
\text { States }\end{array}$ \\
\hline NCT02804945 & $\begin{array}{l}\text { MSCs for treatment of } \\
\text { acute respiratory distress } \\
\text { syndrome (ARD) in } \\
\text { patients with malignan- } \\
\text { cies }\end{array}$ & Phase 1 & Completed & $\begin{array}{l}\text { M.D. Anderson Cancer } \\
\text { Center }\end{array}$ & Texas, United States \\
\hline NCT02181478 & $\begin{array}{l}\text { Intra-osseous co-transplant } \\
\text { of Cord Blood and MSCs }\end{array}$ & Early Phase 1 & Active, not recruiting & $\begin{array}{l}\text { Marcos de Lima, Case } \\
\text { Comprehensive Cancer } \\
\text { Center }\end{array}$ & Ohio, United States \\
\hline NCT00790413 & $\begin{array}{l}\text { Haploidentical stem } \\
\text { cell transplantation in } \\
\text { neuroblastoma }\end{array}$ & Early Phase 1 & Active, not recruiting & $\begin{array}{l}\text { JacekToporski, Lund Uni- } \\
\text { versity Hospital }\end{array}$ & Lund, Sweden \\
\hline
\end{tabular}

and aging could be a next-generation therapy in the field of drug development. Thus far, MSCs-based therapy has been reported in the diseases mentioned above. Conventional cancer treatment involves the use of chemotherapeutic drugs, which are designed to suppress rapidly growing cancerous cells; however, long-term use of chemotherapy drugs has resulted in resistance to the therapy for which they were used. Chemotherapy is also known to cause damage to healthy cells, specifically the dividing cells in the bone marrow and the gut. Several adverse effects have been observed depending on the nature of the drug. For instance, alkylating agents are known to damage DNA to prevent cancerous cells from dividing directly but at the same time are capable of inducing long term damage to the bone marrow and eventually resulting in leukaemia [108]. MSCs may serve as a potential cell-based therapy for diseases like cancer in a personalized manner and can be effectively used as delivery vehicles to carry therapeutic factors. Furthermore, finding a cure for neurodegenerative disease such as Alzheimer's has been a real challenge because they are not only difficult to diagnose, but drug delivery to the brain is also an intricate process. MSCs-based therapy can reinforce nerve growth by reconstructing the neural microenvironment and reducing the factors involved in damaging the nerve structure, thereby providing a treatment [109]. Another application of MSCs-based therapy has been observed for frailty, although it is known that certain diets can improve the symptoms of frailty. There is currently no treatment available to prevent the frailty syndrome. MSCs can be drawn to the injury site and reduce inflammation while promoting cellular repair to improve frailty conditions. [110].

\section{Complications and controversies on MSCs therapies}

MSCs have tremendous potential for targeted cellular therapy against several chronic inflammatory diseases [101]. The ongoing application of MSCs in clinical trials suggests that these cells can target therapy in several types of cancers. However, recent research on anti-tumour properties of MSCs still revolves around several controversies. Researchers have differing perspectives on MSCs-targeted cell therapy. Some studies have demonstrated proliferative effects of MSCs, while others have demonstrated an inhibitory role in tumour progression. For example, MSCs 
have a direct tumoricidal impact on lung and liver cancer cells, while proliferation and metastasis affects breast and colon cancer [111]. Because most MSCs-based clinical trials are still in their infancy, the efficacy and efficiency of these therapies may improve further with refinement of the route of delivery, dosage, and a better understanding of the biological action [112]. Initial successful results of MSCsbased therapy in animal models may create complications in a patient due to various factors that are not accounted for in animal models. It has been observed that relatively small lesions generated in CNS of mice are easy to repair by MSCs in comparison to large lesions in humans. It was also revealed that immune cells respond differently to MSCs-derived signals in human and animal models [113]. The safety and potential side-effects of MSCs infusion in humans need a better understanding before starting with MSCs therapy as the risk of infection needs to be assessed in case of MSCs treatment due to its suppressing immunosuppressive properties that increase the likelihood of tumor formation. Still, several ongoing clinical trials of MSCs have revealed minimal potential complications. However, treatment of chronic conditions requires multiple infusions of MSCs over a protracted period. In that case, the risk of adverse events may increase [102, 114].

\section{Conclusion}

There are cases in which the appropriate increase in ROS level is associated with various diseases, such as cancer, neurodegeneration, kidney failure, etc. Stem cells, especially MSCs, have evolved various redox systems that protect them against ROS-induced oxidative stress. The fine-tuning between the cell cycle and redox status is an important mechanism that stem cells adopt during oxidative stress. FoxO is a transcription factor that controls the intrinsic ROS level. Like MSCs, some other stem cells, like HSCs also regulate ROS stress through ATM gene expression. The potential of cellular metabolism regulation by MSCs helps control ROS production, which decreases oxidative stress. The anti-tumor properties and anti-inflammatory potential of MSCs help regulate oxidative stress through the secretion of various soluble factors, such as sT $\beta$ R, HGF, PGE2, SOD1, IL1RN, and SOD3. These soluble factors control the inflammatory reaction and help in the regulation of oxidative damages induced by ROS present in the cells. MSCs can also regulate MAPKs, JNKs, p38, and ERKs activated downstream of ROS in the cell. These properties may increase the likelihood of using MSCs as an alternative therapy to reduce oxidative stress.
Author contributions All authors participated equally in designing the study, drafting, writing, editing the manuscript, and approving it for submission. Figures are created by BioRender.com.

Funding Authors like to thank Director, INMAS, Delhi, for the encouragement and funding.

\section{Declarations}

Conflict of interest We have no conflict of interest.

Research involving human participants and/or animals Not applicable.

Informed consent Not applicable.

\section{References}

1. Fransen M, Nordgren M, Wang B, Apanasets O. Role of peroxisomes in ROS/RNS-metabolism: implications for human disease. Biochim Biophys Acta - Mol Basis Dis. 2012;1822:136373. https://doi.org/10.1016/j.bbadis.2011.12.001.

2. Przerwa A, Zimecki M, Świtała-Jeleń K, et al. Effects of bacteriophages on free radical production and phagocytic functions. Med Microbiol Immunol. 2006;195:143-50. https://doi.org/10. 1007/s00430-006-0011-4.

3. Flores-Martín J, Reyna L, Ridano ME, et al. Suppression of StarD7 promotes endoplasmic reticulum stress and induces ROS production. Free Radic Biol Med. 2016;99:286-95. https://doi.org/10.1016/j.freeradbiomed.2016.08.023.

4. Starkov AA. Measurement of mitochondrial ROS production. In: Methods in molecular biology. Humana Press Inc.; 2010. p. $245-55$.

5. Balaban RS, Nemoto S, Finkel T. Mitochondria, oxidants, and aging. Cell. 2005;120:483-95. https://doi.org/10.1016/j.cell. 2005.02.001.

6. Bergamini C, Gambetti S, Dondi A, Cervellati C. Oxygen, reactive oxygen species and tissue damage. Curr Pharm Des. 2005;10:1611-26. https://doi.org/10.2174/1381612043384664.

7. Fridavich I. Superoxide radical and superoxide dismutases. Annu Rev Biochem. 1995;64:97-112. https://doi.org/10.1146/ annurev.bi.64.070195.000525.

8. Neill S, Desikan R, Hancock J. Hydrogen peroxide signalling. Curr Opin Plant Biol. 2002;5:388-95. https://doi.org/10.1016/ S1369-5266(02)00282-0.

9. Cadet J, Delatour T, Douki T, et al. Hydroxyl radicals and DNA base damage. Mutat Res - Fundam Mol Mech Mutagen. 1999;424:9-21. https://doi.org/10.1016/S0027-5107(99) 00004-4.

10. Phaniendra A, Jestadi DB, Periyasamy L. Free radicals: properties, sources, targets, and their implication in various diseases. Indian J Clin Biochem. 2015;30:11-26. https://doi.org/ 10.1007/s12291-014-0446-0.

11. Boonstra J, Post JA. Molecular events associated with reactive oxygen species and cell cycle progression in mammalian cells. Gene. 2004;337:1-13. https://doi.org/10.1016/j.gene.2004.04. 032.

12. Sauer H, Wartenberg M, Hescheler J. Reactive oxygen species as intracellular messengers during cell growth and differentiation. Cell Physiol Biochem. 2001;11:173-86. https://doi.org/ $10.1159 / 000047804$. 
13. Zhang H, Menzies KJ, Auwerx J. The role of mitochondria in stem cell fate and aging. Dev. 2018. https://doi.org/10.1242/dev. 143420.

14. Rhee SG. Redox signaling: hydrogen peroxide as intracellular messenger. Exp Mol Med. 1999;31:53-9. https://doi.org/10. 1038/emm.1999.9.

15. Martin KR, Barrett JC. Reactive oxygen species as double-edged swords in cellular processes: low-dose cell signaling versus highdose toxicity. Hum Exp Toxicol. 2002;21:71-5. https://doi.org/ 10.1191/0960327102ht213oa.

16. Aggarwal V, Tuli HS, Varol A, et al. Role of reactive oxygen species in cancer progression: molecular mechanisms and recent advancements. Biomolecules. 2019. https://doi.org/10.3390/ biom9110735.

17. Nijmeh J, Moldobaeva A, Wagner EM. Role of ROS in ischemiainduced lung angiogenesis. Am J Physiol - Lung Cell Mol Physiol. 2010;299:535-41. https://doi.org/10.1152/ajplung.00002. 2010.

18. Samimi A, Khodayar MJ, Alidadi H, Khodadi E. The dual role of ROS in hematological malignancies: stem cell protection and cancer cell metastasis. Stem Cell Rev Reports. 2020;16:262-75. https://doi.org/10.1007/s12015-019-09949-5.

19. Brown SA. Oxidative stress and chronic kidney disease. Vet Clin North Am - Small Anim Pract. 2008;38:157-66. https://doi.org/ 10.1016/j.cvsm.2007.11.001.

20. Halliwell B. Oxygen radicals as key mediators in neurological disease: fact or fiction? Ann Neurol. 1992;32:S10-5. https://doi. org/10.1002/ana.410320704.

21. Haycock JW, Mac Neil S, Jones P, et al. Oxidative damage to muscle protein in Duchenne muscular dystrophy. NeuroReport. 1997;8:357-61. https://doi.org/10.1097/00001756-19961 2200-00070.

22. Salunga TL, Cui ZG, Shimoda S, et al. Oxidative stress-induced apoptosis of bile duct cells in primary biliary cirrhosis. J Autoimmun. 2007;29:78-86. https://doi.org/10.1016/j.jaut.2007.04.002.

23. Kim J, Kim J, Bae JS. ROS homeostasis and metabolism: a critical liaison for cancer therapy. Exp Mol Med. 2016;48:e269-313. https://doi.org/10.1038/emm.2016.119.

24. García-Castro J, Trigueros C, Madrenas J, et al. Mesenchymal stem cells and their use as cell replacement therapy and disease modelling tool. J Cell Mol Med. 2008;12:2552-65. https://doi. org/10.1111/j.1582-4934.2008.00516.x.

25. Spaeth E, Klopp A, Dembinski J, et al. Inflammation and tumor microenvironments: defining the migratory itinerary of mesenchymal stem cells. Gene Ther. 2008;15:730-8. https://doi.org/ 10.1038/gt.2008.39.

26. Parekkadan B, Milwid JM. Mesenchymal stem cells as therapeutics. Annu Rev Biomed Eng. 2010;12:87-117. https://doi.org/10. 1146/annurev-bioeng-070909-105309.

27. Mittal M, Siddiqui MR, Tran K, et al. Reactive oxygen species in inflammation and tissue injury. Antioxidants Redox Signal. 2014;20:1126-67.

28. Meng LQ, Wang Y, Luo YH, et al. Quinalizarin induces apoptosis through reactive oxygen species (ROS)-mediated mitogenactivated protein kinase (MAPK) and signal transducer and activator of transcription 3 (STAT3) signaling pathways in colorectal cancer cells. Med Sci Monit. 2018;24:3710-9.

29. Alfadda AA, Sallam RM. Reactive oxygen species in health and disease. J Biomed Biotechnol. 2012. https://doi.org/10.1155/ 2012/936486

30. Uttara B, Singh AV, Zamboni P, Mahajan RT. Oxidative stress and neurodegenerative diseases: a review of upstream and downstream antioxidant therapeutic options. Curr Neuropharmacol. 2009;7(1):65-74.

31. Katsuya-gaviria K, Caro E, Carrillo-barral N, Iglesias-fernández R. Reactive oxygen species (ROS) and nucleic acid modifications during seed dormancy. Plants. 2020. https://doi.org/10.3390/ plants 9060679 .

32. Schieber M, Chandel NS. ROS function in redox signaling and oxidative stress. Curr Biol. 2014;24:R453-62. https://doi.org/10. 1016/j.cub.2014.03.034

33. Naik E, Dixit VM. Mitochondrial reactive oxygen species drive proinflammatory cytokine production. J Exp Med. 2011;208:417-20.

34. Morgan MJ, Liu ZG. Crosstalk of reactive oxygen species and NF-кB signaling. Cell Res. 2011;21:103-15. https://doi.org/10. 1038/cr.2010.178.

35. Simon AR, Rai U, Fanburg BL, Cochran BH. Activation of the JAK-STAT pathway by reactive oxygen species. Am J Physiol. 1998;275(6):1640-52.

36. Son Y, Cheong Y-K, Kim N-H, et al. Mitogen-activated protein kinases and reactive oxygen species: how can ROS activate MAPK pathways? J Signal Transduct. 2011;2011:1-6. https:// doi.org/10.1155/2011/792639.

37. Yin J, Ren W, Wu X, et al. Oxidative stress-mediated signaling pathways: a review. J Food, Agric Environ. 2013;11:132-9.

38. Zhao J, Fujita K, Sakai K. Reactive oxygen species, nitric oxide, and their interactions play different roles in Cupressus lusitanica cell death and phytoalexin biosynthesis. New Phytol. 2007;175:215-29. https://doi.org/10.1111/j.1469-8137.2007. 02109.x.

39. Kim H, Yun J, Kwon SM. Therapeutic strategies for oxidative stress-related cardiovascular diseases: removal of excess reactive oxygen species in adult stem cells. Oxid Med Cell Longev. 2016. https://doi.org/10.1155/2016/2483163.

40. Hensley K, Robinson KA, Gabbita SP, et al. Reactive oxygen species, cell signaling, and cell injury. Free Radic Biol Med. 2000;28:1456-62. https://doi.org/10.1016/S0891-5849(00) 00252-5.

41. Jang JH, Chun JN, Godo S, et al. ROS and endothelial nitric oxide synthase (eNOS)-dependent trafficking of angiotensin II type 2 receptor begets neuronal NOS in cardiac myocytes. Basic Res Cardiol. 2015. https://doi.org/10.1007/s00395-015-0477-6.

42. Förstermann U, Li H. Therapeutic effect of enhancing endothelial nitric oxide synthase (eNOS) expression and preventing eNOS uncoupling. Br J Pharmacol. 2011;164:213-23. https://doi.org/ 10.1111/j.1476-5381.2010.01196.x.

43. Yamaguchi T, Kamada K, Dayton C, et al. Role of eNOS-derived $\mathrm{NO}$ in the postischemic anti-inflammatory effects of antecedent ethanol ingestion in murine small intestine. Am J Physiol - Hear Circ Physiol. 2007;292:1435-42. https://doi.org/10.1152/ajphe art.00282.2006.

44. Aoyagi M, Arvai AS, Tainer JA, Getzoff ED. Structural basis for endothelial nitric oxide synthase binding to calmodulin. EMBO J. 2003;22:766-75. https://doi.org/10.1093/emboj/cdg078.

45. Rimessi A, Previati M, Nigro F, et al. Mitochondrial reactive oxygen species and inflammation: molecular mechanisms, diseases and promising therapies. Int J Biochem Cell Biol. 2016;81:28193. https://doi.org/10.1016/j.biocel.2016.06.015.

46. McCubrey JA, LaHair MM, Franklin RA. Reactive oxygen species-induced activation of the MAP kinase signaling pathways. Antioxidants Redox Signal. 2006;8:1775-89. https://doi.org/10. 1089/ars.2006.8.1775.

47. Li X, Fang P, Mai J, et al. Targeting mitochondrial reactive oxygen species as novel therapy for inflammatory diseases and cancers. J Hematol Oncol. 2013;6:1-19. https://doi.org/10.1186/ 1756-8722-6-19.

48. Han D, Ybanez MD, Ahmadi S, et al. Redox regulation of tumor necrosis factor signaling. Antioxidants Redox Signal. 2009;11:2245-63. https://doi.org/10.1089/ars.2009.2611.

49. Lane T, Flam B, Lockey R, Kolliputi N. TXNIP shuttling: Missing link between oxidative stress and inflammasome 
activation. Front Physiol. 2013;4:3-5. https://doi.org/10.3389/ fphys.2013.00050.

50. Shah A, Xia L, Goldberg H, et al. Thioredoxin-interacting protein mediates high glucose-induced reactive oxygen species generation by mitochondria and the nadph oxidase, Nox4, in mesangial cells. J Biol Chem. 2013;288:6835-48. https://doi. org/10.1074/jbc.M112.419101.

51. Wen H. Oxidative stress-mediated effects of angiotensin II in the cardiovascular system. World J Hypertens. 2012;2:34. https://doi.org/10.5494/wjh.v2.i4.34.

52. Panth N, Paudel KR, Parajuli K. Reactive oxygen species: a key hallmark of cardiovascular disease. Adv Med. 2016;2016:1-12. https://doi.org/10.1155/2016/9152732.

53. Spooner R, Yilmaz Ö. The role of reactive-oxygen-species in microbial persistence and inflammation. Int J Mol Sci. 2011;12:334-52. https://doi.org/10.3390/ijms12010334.

54. Minutoli L, Puzzolo D, Rinaldi M, et al. ROS-mediated NLRP3 inflammasome activation in brain, heart, kidney, and testis ischemia/reperfusion injury. Oxid Med Cell Longev. 2016. https://doi.org/10.1155/2016/2183026.

55. Fouser LA, Wright JF, Dunussi-Joannopoulos K, Collins M. Th17 cytokines and their emerging roles in inflammation and autoimmunity. Immunol Rev. 2008;226:87-102. https://doi. org/10.1111/j.1600-065X.2008.00712.x.

56. Simon HU, Haj-Yehia A, Levi-Schaffer F. Role of reactive oxygen species (ROS) in apoptosis induction. Apoptosis. 2000;5:415-8. https://doi.org/10.1023/A:1009616228304.

57. Sethu S, Melendez AJ. New developments on the TNF $\alpha$ mediated signalling pathways. Biosci Rep. 2011;31:63-76. https://doi.org/10.1042/BSR20100040.

58. Tysnes BB, Bjerkvig R. Cancer initiation and progression: Involvement of stem cells and the microenvironment. Biochim Biophys Acta - Rev Cancer. 2007;1775:283-97. https://doi.org/ 10.1016/j.bbcan.2007.01.001.

59. Fan JJ, Hsu WH, Hung HH, et al. Reduction in MnSOD promotes the migration and invasion of squamous carcinoma cells. Int J Oncol. 2019;54:1639-50. https://doi.org/10.3892/ ijo.2019.4750.

60. Geiger TR, Peeper DS. Metastasis mechanisms. Biochim Biophys Acta - Rev Cancer. 2009;1796:293-308. https://doi.org/10. 1016/j.bbcan.2009.07.006.

61. Chaffer CL, Weinberg RA. A perspective on cancer cell metastasis. Science (80-). 2011;331:1559-64. https://doi.org/10.1126/ science. 1203543

62. Taki M, Verschueren K, Yokoyama K, et al. Involvement of Ets-1 transcription factor in inducing matrix metalloproteinase-2 expression by epithelial-mesenchymal transition in human squamous carcinoma cells. Int J Oncol. 2006;28:487-96. https://doi. org/10.3892/ijo.28.2.487.

63. Schwabe RF, Brenner DA. Mechanisms of liver injury. I. TNF- $\alpha-$ induced liver injury: Role of IKK, JNK, and ROS pathways. Am J Physiol - Gastrointest Liver Physiol. 2006;290:583-9. https:// doi.org/10.1152/ajpgi.00422.2005.

64. Aydin E, Johansson J, Nazir FH, et al. Role of NOX2-derived reactive oxygen species in NK cell-mediated control of murine melanoma metastasis. Cancer Immunol Res. 2017;5:804-11. https://doi.org/10.1158/2326-6066.CIR-16-0382.

65. Rajabi M, Mousa SA. The role of angiogenesis in cancer treatment. Biomedicines. 2017. https://doi.org/10.3390/biomedicin es5020034

66. Quintero-Fabián S, Arreola R, Becerril-Villanueva E, et al. Role of matrix metalloproteinases in angiogenesis and cancer. Front Oncol. 2019;9:1-21. https://doi.org/10.3389/fonc.2019.01370.

67. Nimse SB, Pal D. Free radicals, natural antioxidants, and their reaction mechanisms. RSC Adv. 2015;5:27986-8006. https://doi. org/10.1039/c4ra13315c.
68. Wei X, Yang X, Han ZP, et al. Mesenchymal stem cells: a new trend for cell therapy. Acta Pharmacol Sin. 2013;34:747-54. https://doi.org/10.1038/aps.2013.50.

69. Minguell JJ, Erices A, Conget P. Mini-review: mesenchymal cells. Stem Cell Technol. 2001;226:1-5. https://doi.org/10.1177/ 153537020122600603.

70. Caplan AI, Haynesworth SE. Method for treating connective tissue disorders. 'U.S Patent 5,226,914, issued July 13, 1993.

71. Dominici M, Le Blanc K, Mueller I, et al. Minimal criteria for defining multipotent mesenchymal stromal cells. The International Society for Cellular Therapy position statement. Cytotherapy. 2006;8:315-7. https://doi.org/10.1080/14653240600855905.

72. Perasso L, Cogo CE, Giunti D, et al. Systemic administration of mesenchymal stem cells increases neuron survival after global cerebral ischemia in vivo (2VO). Neural Plast. 2010;2010:11-4. https://doi.org/10.1155/2010/534925.

73. Li M, Ikehara S. Bone-marrow-derived mesenchymal stem cells for organ repair. Stem Cells Int. 2013. https://doi.org/10.1155/ 2013/132642.

74. Si YL, Zhao YL, Hao HJ, et al. MSCs: Biological characteristics, clinical applications and their outstanding concerns. Ageing Res Rev. 2011;10:93-103. https://doi.org/10.1016/j.arr.2010.08.005.

75. Wang M, Yuan Q, Xie L. Mesenchymal stem cell-based immunomodulation: properties and clinical application. Stem Cells Int. 2018. https://doi.org/10.1155/2018/3057624.

76. Baglio SR, Pegtel DM, Baldini N. Mesenchymal stem cell secreted vesicles provide novel opportunities in (stem) cell-free therapy. Front Physiol. 2012;3:1-12. https://doi.org/10.3389/ fphys.2012.00359.

77. Zheng G, Huang R, Qiu G, et al. Mesenchymal stromal cellderived extracellular vesicles: regenerative and immunomodulatory effects and potential applications in sepsis. Cell Tissue Res. 2018;374:1-15. https://doi.org/10.1007/s00441-018-2871-5.

78. Fontaine MJ, Shih H, Schäfer R, Pittenger MF. Unraveling the mesenchymal stromal cells' paracrine immunomodulatory effects. Transfus Med Rev. 2016;30:37-43. https://doi.org/10. 1016/j.tmrv.2015.11.004.

79. Stagg J. Mesenchymal stem cells in cancer. Stem Cell Rev. 2008;4:119-24. https://doi.org/10.1007/s12015-008-9030-4.

80. Raman D, Baugher PJ, Thu YM, Richmond A. Role of chemokines in tumor growth. Cancer Lett. 2007;256:137-65. https://doi.org/10.1016/j.canlet.2007.05.013.

81. Cheng M, Qin G. Progenitor cell mobilization and recruitment: SDF-1, CXCR4, prog mol biol trans1 sci $\alpha 4$-integrin, and c-kit. Prog Mol Biol Transl Sci. 2012;111:243-64. https://doi.org/10. 1016/B978-0-12-398459-3.00011-3.Progenitor.

82. Sohni A, Verfaillie CM. Mesenchymal stem cells migration homing and tracking. Stem Cells Int. 2013;2013:14-6. https://doi.org/ 10.1155/2013/130763

83. Ke C, Chen J, Guo Y, et al. Migration mechanism of mesenchymal stem cells studied by QD/NSOM. Biochim Biophys Acta - Biomembr. 2015;1848:859-68. https://doi.org/10.1016/j. bbamem.2014.12.013.

84. Zhang J, Nuebel E, Daley GQ, et al. Metabolic regulation in pluripotent stem cells during reprogramming and self-renewal. Cell Stem Cell. 2012;11:589-95. https://doi.org/10.1016/j.stem. 2012.10.005.

85. Bartczak A, McGilvray I, Keating A. Mesenchymal stromal cell therapy to promote cardiac tissue regeneration and repair. Curr Opin Organ Transplant. 2017;22:86-96. https://doi.org/10.1097/ MOT.0000000000000379.

86. Kobayashi CI, Suda T. Regulation of reactive oxygen species in stem cells and cancer stem cells. J Cell Physiol. 2012;227:42130. https://doi.org/10.1002/jcp.22764.

87. Mancuso P, Raman S, Glynn A, et al. Mesenchymal stem cell therapy for osteoarthritis: the critical role of the cell secretome. 
Front Bioeng Biotechnol. 2019. https://doi.org/10.3389/fbioe. 2019.00009.

88. Elmarakby AA, Sullivan JC. Relationship between oxidative stress and inflammatory cytokines in diabetic nephropathy. Cardiovasc Ther. 2012;30:49-59. https://doi.org/10.1111/j.17555922.2010.00218.x.

89. Park J, Min JS, Kim B, et al. Mitochondrial ROS govern the LPSinduced pro-inflammatory response in microglia cells by regulat-

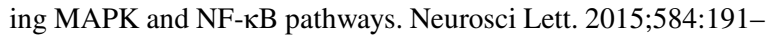
6. https://doi.org/10.1016/j.neulet.2014.10.016.

90. Jeong Hong H, Kim H, Woon Park C, et al. Cytokine secretion profiling of human mesenchymal stem cells by antibody array. Int J Stem Cells. 2009;2:59-68.

91. Bouffi C, Bony C, Courties G, et al. IL-6-dependent PGE2 secretion by mesenchymal stem cells inhibits local inflammation in experimental arthritis. PLoS ONE. 2010. https://doi.org/10.1371/ journal.pone.0014247.

92. Yin W, Robyn B, Alycia N, Siegfired H. Superoxide dismutases: Dual roles in controlling ROS damage and regulating ROS signaling. J Cell Biol. 2018;217:1915-28. https://doi.org/10.1083/ jcb.201708007.

93. Xu S, Liu C, Ji HL. Concise review: therapeutic potential of the mesenchymal stem cell derived secretome and extracellular vesicles for radiation-induced lung injury: progress and hypotheses. Stem Cells Transl Med. 2019;8:344-54. https://doi.org/10.1002/ sctm.18-0038.

94. Cheung TS, Bertolino GM, Giacomini C, et al. Mesenchymal stromal cells for graft versus host disease: mechanism-based biomarkers. Front Immunol. 2020;11:1-15. https://doi.org/10.3389/ fimmu.2020.01338.

95. Bagno L, Hatzistergos KE, Balkan W, Hare JM. Mesenchymal stem cell-based therapy for cardiovascular disease: progress and challenges. Mol Ther. 2018;26:1610-23. https://doi.org/10. 1016/j.ymthe.2018.05.009.

96. Liang J, Sun L. Mesenchymal stem cells transplantation for systemic lupus erythematosus. Int J Rheum Dis. 2015;18:164-71. https://doi.org/10.1111/1756-185X.12531.

97. Tsuchiya A, Takeuchi S, Watanabe T, et al. Mesenchymal stem cell therapies for liver cirrhosis: MSCs as "conducting cells" for improvement of liver fibrosis and regeneration. Inflamm Regen. 2019;39:4-9. https://doi.org/10.1186/s41232-019-0107-z.

98. Hmadcha A, Martin-Montalvo A, Gauthier BR, et al. Therapeutic potential of mesenchymal stem cells for cancer therapy. Front Bioeng Biotechnol. 2020;8:1-13. https://doi.org/10.3389/fbioe. 2020.00043.

99. Chu D-T, Nguyen TT, Tien NLB, et al. Recent progress of stem cell therapy in cancer treatment: molecular mechanisms and potential applications. Cells. 2020;9:563. https://doi.org/10.3390/ cells9030563.

100. Kavianpour M, Saleh M, Verdi J. The role of mesenchymal stromal cells in immune modulation of COVID-19: focus on cytokine storm. Stem Cell Res Ther. 2020. https://doi.org/10. 1186/s13287-020-01849-7.

101. Gnecchi M, Danieli P, Cervio E. Mesenchymal stem cell therapy for heart disease. Vascul Pharmacol. 2012;57:48-55. https://doi. org/10.1016/j.vph.2012.04.002.

102. Squillaro T, Peluso G, Galderisi U. Clinical trials with mesenchymal stem cells: an update. Cell Transplant. 2016;25:829-48. https://doi.org/10.3727/096368915X689622.

103. Fortier LA. Stem cells: classifications, controversies, and clinical applications. Vet Surg. 2005;34:415-23. https://doi.org/10. 1111/j.1532-950X.2005.00063.x.

104. Park KS, Bandeira E, Shelke GV, et al. Enhancement of therapeutic potential of mesenchymal stem cell-derived extracellular vesicles. Stem Cell Res Ther. 2019;10:1-15. https://doi.org/10. 1186/s13287-019-1398-3.

105. Xunian Z, Kalluri R. Biology and therapeutic potential of mesenchymal stem cell-derived exosomes. Cancer Sci. 2020;111:310010. https://doi.org/10.1111/cas.14563.

106. Chang AI, Nolta JA, Wu J. Mesenchymal stem cells as a carrier for tumor-targeting therapeutics. Stem Cell-Dependent Ther Mesenchymal Stem Cells Chronic Inflamm Disord. 2013. https:// doi.org/10.1515/9783110298307.353.

107. "Home - ClinicalTrials.gov" https://clinicaltrials.gov/. Accessed 17 Jul 2020.

108. Khuda-Bukhsh AR, Mondal J, Panigrahi AK. Conventional chemotherapy : problems and scope for combined therapies with certain herbal products and dietary supplements. Austin J Mol Cell Biol. 2014;1:1-10.

109. Yao P, Zhou L, Zhu L, et al. Mesenchymal stem cells: a potential therapeutic strategy for neurodegenerative diseases. Eur Neurol. 2020;83:235-41.

110. Schulman IH, Balkan W, Hare JM. Mesenchymal stem cell therapy for aging frailty. Front Nutr. 2018;5:2-11. https://doi.org/10. 3389/fnut.2018.00108.

111. Liu T, Zhu K, Ke C, et al. Mesenchymal stem cells inhibited development of lung cancer induced by chemical carcinogens in a rat model. Am J Transl Res. 2017;9:2891-900.

112. Darkazalli A. Mesenchymal stem cell therapy for traumatic brain injury: cellular and molecular mechanisms. 2015.

113. Banerjee $\mathrm{S}$. Transplantation in acute ischaemic stroke. Lancet. 2012;380(9847): 1054.

114. Lukomska B, Stanaszek L, Zuba-Surma E, et al. Challenges and controversies in human mesenchymal stem cell therapy. Stem Cells Int. 2019. https://doi.org/10.1155/2019/9628536.

Publisher's Note Springer Nature remains neutral with regard to jurisdictional claims in published maps and institutional affiliations. 